\title{
JAMINAN HUKUM TERHADAP WAJIB PAJAK DALAM PENYELESAIAN SENGKETA PAJAK
}

\author{
Liberthin Palullungan, Ririn Thomas \\ Universitas Kristen Paulus, liberthin@ukipaulus.ac.id
}

\begin{abstract}
Abstrak
Di dalam kehidupan bernegara, dimana ada hubungan antara manusia dengan manusia, selalu ada peraturan yang mengikatnya yakni hukum. Hukum mengatur tentang hak dan kewajiban manusia. Tujuan penelitian ini adalah untuk mengetahui factor apa saja yang dapat menghambat proses penyelesaian sengketa pajak. Penelitian ini menggunakan tipe penelitian yuridis normatif yang bersumberkan bahan primer dan sekunder, yang dianalisis secara kualitatif dengan menguraikan secara deskriptif hasil data yang ada. Hasil penelitian ini menunjukkan bahwa faktor-faktor yang menghambat proses penyelesaian sengketa pajak adalah faktor di bidang Administratif yaitu adanya keharusan terlebih dahulu wajib pajak membayar 50\% (limapuluh persen) dari jumlah pajak yang terutang. Kemudian dibidang Yudisial yaitu mengenai kewajiban Hakim untuk menghadirkan pihak terbanding atau tergugat dalam pemeriksaan dipersidangan.

Kata Kunci : Sengketa Pajak, Wajib Pajak
\end{abstract}

\begin{abstract}
In the life of the state, where there is a relationship between humans and humans, there are always rules that bind it, namely the law. Law regulates human rights and obligations. The purpose of this study is to find out what factors can hinder the process of resolving tax disputes. This research uses type. This study uses a type of normative juridical research sourced from primary and secondary materials, which were analyzed qualitatively by descriptively describing the results of the existing data. The results of this study indicate that the factors that hinder the process of resolving tax disputes are factors in the administration sector, namely the existence of the first obligation of the Taxpayer to pay 50\% (fifty percent) of the total tax payable. Then in the field of justice, namely regarding the obligation of judges to present the appellate party or defendant in examination at trial.

Keywords: Tax Dispute, Taxpayer
\end{abstract}

\section{Pendahuluan}

Penegakan hukum pajak dalam sengketa pajak pada hakekatnya untuk memberikan perlindungan hukum, baik kepada wajib pajak maupun pejabat pajak sebagai wakil Negara. ${ }^{1}$ Pajak adalah kesepakatan yang timbul berdasarkan UndangUndang. Kesepakatan tersebut terjalin antara Dewan Perwakilan Rakyat dengan Presiden, karena negara memerlukan pajak untuk membiayai penyelenggaraan pemerintahan negara. Hal ini menunjukkan bahwa pajak adalah pembayaran wajib

\footnotetext{
${ }^{1}$ Etty Rochaeti, 2012, Perlindungan Hukum Bagi Wajib Pajak Dalam Penyelesaian Sengketa Pajak, Jurnal Wawasan Hukum, Voumel 26 Nomor 1., hlm. 499
} 
yang dikenakan berdasarkan undang-undang yang tidak dapat dihindari bagi yang berkewajiban dan bagi mereka yang tidak mau membayar pajak dapat dilakukan paksaan. Dengan demikian, akan terjamin bahwa kas negara selalu berisi uang pajak. Selain itu, pengenaan pajak berdasarkan undang-undang akan menjamin adanya keadilan dan kepastian hukum bagi pembayar pajak sehingga pemerintah tidak dapat sewenangwenang menetapkan besarnya pajak. ${ }^{2}$

Definisi pajak itu sendiri yaitu iuran rakyat kepada kas negara berdasarkan undang-undang ( yang dapat dipaksakan ) dengan tidak mendapat jasa timbal ( kontra prestasi ) yang langsung dapat ditunjuk dan digunakan untuk membayar pengeluaran umum. ${ }^{3}$ Lebih lanjut dijelaskan bahwa pajak adalah " Perikatan yang timbul karena undang-undang yang mewajibkan seseorang yang memenuhi syarat ( taatbestand ) yang ditentukan dalam undang-undang untuk membayar sejumlah uang tertentu kepada negara yang dapat dipaksakan dengan tidak mendapat imbalan secara langsung dapat ditunjuk yang digunakan untuk membiayai pengeluaran-pengeluaran Negara. ${ }^{4}$

Berdasarkan definisi tersebut terlihat bahwa dalam proses pemungutan pajak akan selalu melibatkan dua pihak yakni negara dan rakyat ( wajib pajak ). ${ }^{5}$ Penyelesaian sengketa melalui upaya administratif mengingat pemutus sengketa adalah pihak yang masih masuk lingkungan pemerintah yang notabene pihak yang berperkara maka keobyektifan putusannya sering diragukan, sedangkan suatu penyelesaian sengketa selalu dituntut untuk menghasilkan suatu putusan yang obyektif sehingga mampu memberi perlindungan hukum bagi pihak-pihak yang bersengketa.

\section{Metode}

Jenis penelitian ini adalah penelitian normatif yang melakukan pengkajian terhadap peraturan terkait di bidang perpajakan. Data yang digunakan adalah data sekunder yang terdiri dari bahan hukum primer dan bahan hukum sekunder. Data yang dikumpulkan akan dianalisis secara kualitatif dan menguraikan data yang ada secara deskriptif. Selain itu, penulis melakukan serangkaian penelitian dengan memilih lokasi penelitian dalam wilayah hukum Kota Makassar. Pengumpulan data dan informasi akan dilaksanakan di Kantor Pelayanan Pajak Pratama Selatan Makassar dengan pertimbangan bahwa pada lokasi tersebut dapat memberikan informasi terkait penelitian ini.

\footnotetext{
${ }^{2}$ Marihot P. Siahaan, 2005, Pajak Daerah \& Retribusi Daerah, PT RajaGrafindo Persada, Jakarta, hlm. 7

${ }^{3}$ Rochmat Soemitro, 1990, Dasar-dasar Hukum Pajak Dan Pajak Pendapatan, Eresco, Bandung, hlm. 5

${ }^{4}$ Rochmat Soemitro, 1990, Asas Dan Dasar Perpajakan, Jilid 1, Eresco, Bandung, hlm. 51

${ }^{5}$ SF.Marbun, 1997, Peradilan Administrasi Negara Dan Upaya Administratif Di Indonesia, Liberty, Yogyakarta, hlm.66
} 


\section{Bentuk Jaminan Hukum Terhadap Wajib Pajak}

Tingkat kepatuhan wajib pajak adalah salah satu faktor yang mempengaruhi keberhasilan pemungutan pajak. Dalam rangka meningkatkan penerimaan pajak perlu diupayakan peningkatan kepatuhan wajib pajak. Dalam Visi dan Misi Direktorat Jenderal Pajak, Misi pertama adalah mengumpulkan penerimaan berdasarkan kepatuhan pajak sukarela yang tinggi dan penegakan hukum yang adil. Wajib pajak dapat melakukan upaya hukum keberatan terhadap suatu Surat Ketetapan Pajak (SKP) kepada Direktorat Jenderal Pajak (DJP). ${ }^{6}$

Salah faktor yang mempengaruhi kepatuhan wajib pajak adalah persepsi keadilan yang dirasakan oleh wajib pajak. Persepsi keadilan tersebut terbentuk jika wajib pajak menyadari hak-haknya, mengharapkan agar hak-hak tersebut terpenuhi dan jika pada kenyataannya mereka menerima perlakuan yang adil atas hak-hak tersebut maka wajib pajak akan lebih bersedia untuk menjadi patuh terhadap kewajiban perpajakan. Cara-cara otoritas perpajakan berinteraksi dengan wajib pajak akan mempengaruhi persepsi publik tentang sistem perpajakan dan tingkat kepatuhan sukarela. Dalam penyelesaian sengketa pajak seharusnya mampu memberi jaminan kepastian hukum dan rasa keadilan bagi pihak yang bersengketa melalui prosedur dan serta dapat dilakukan proses yang cepat, transparan, murah dan sederhana. ${ }^{7}$

Wajib pajak yang menyadari hak-haknya, mengharapkan agar hak-hak tersebut terpenuhi dan jika pada kenyataannya mereka menerima perlakuan yang adil atas hak-hak tersebut maka wajib pajak akan lebih bersedia untuk menjadi patuh terhadap ketentuan perpajakan. Prosedur keberatan tidak diatur dalam UndangUndang Peradilan Pajak namun diatur dalam Undang-Undang Ketentuaan Umum dan Tata Cara Perpajakan, yang disebutkan dalam Pasal 25 ayat (1). Hal ini menyebabkan wajib pajak dihadapkan pada kekuasaan dan kewenangan Direktorat Jenderal pajak untuk memutuskan, mengabulkan seluruhnya atau sebagian, menolak atau menambah besarnya jumlah pajak yang masih harus dibayar (pasal 26 ayat 3 Undang-Undang KUP) bukan pada kewenangan dan kekuasaan hakim Pengadilan Pajak dalam memutuskan sengketa pajak sesuai yang diatur dalam UndangUndang Pengadilan Pajak. ${ }^{8}$

Hukum pajak materiil dalam memberi kepastian hukum adalah dengan cara memberi pengaturan yang jelas dan tegas dan menimbulkan multi tafsir. hukum pajak material yang membuat norma-norma yang menerangkan keadaan-keadaan, perbuatan-perbuatan dan peristiwa-peristiwa hukum yang harus dikenakan pajak, siapa-siapa yang yang harus dikenakan pajak-pajak ini, berapa besar pajaknya,

\footnotetext{
${ }^{6}$ Fidel, 2014, Tax Law : Proses Beracara di Pengadilan Pajak dan Peradilan Umum, PT Carofin Media, Tangerang, hlm. 27.

${ }^{7}$ Sutrisno, 2010, Penyelesaian Sengketa Pajak, Liga Hukum, hlm. 15

${ }^{8}$ Etty Rochaeti, Op.cit. hlm. 12.
} 
dengan perkataan lain segala sesuatu tentang timbulnya, besarnya, hapusnya hutang pajak dan hubungan hukum antara pemerintah dan Wajib Pajak. Sedangkan hukum pajak formil peraturan-peraturan mengenai cara-cara untuk menjelmakan hukum material tersebut menjadi kenyataan. Maksud hukum pajak formil adalah untuk melindungi baik fiskus (otoritas perpajakan) maupun wajib pajak, jadi untuk memberikan jaminan bahwa hukum pajak materialnya dapat dilaksanakan setepattepatnya.

Hukum pajak formil dan hukum pajak materiil berusaha memberikan kepastian hukum bagi wajib pajak dengan cara selalu melakukan perubahan setiap kali terjadi perubahan ekonomi, sosial dan tehnologi kondisi yang signifikan. Perubahan tersebut sejalan dengan prinsip legalitas bahwa setiap peristiwa dan keadaan yang menimbulkan konsekuensi pajak harus ada hukum yang mengaturnya. Komitment untuk menyesuaikan dengan perkembangan dan perubahan tertuang dalam bagian konsideran perubahan undang-undang. Berkaitan dengan hal tersebut dapat dikatakan bahwa memungut pajak merupakan hak atau kewenangan istimewa yang dimiliki negara. Hak istimewa negara tersebut dikenal dengan exorbitente rechten yaitu hak istimewa negara atau luar biasa yang hanya dimiliki oleh negara yang berdaulat. ${ }^{9}$

Pengadilan pajak merupakan Pengadilan tingkat pertama dan terakhir dalam memeriksa dan memutus Sengketa pajak. Hal ini lebih ditegaskan lagi dalam Pasal 77 ayat (1) Undang-Undang Nomor 14 Tahun 2002 tentang Pengadilan Pajak yang menyatakan bahwa "Putusan Pengadilan Pajak merupakan putusan akhir dan berkekuatan hukum tetap." Dengan demikian Pengadilan Pajak adalah lembaga peradilan yang pertama dan terakhir yang putusannya bersifat final dan mengikat, jadi tidak memiliki pengadilan tingkat banding dan kasasi sebagaimana dalam sistem peradilan dalamlembaga-lembaga peradilan yang lain. Tidak adanya upaya hukum banding dan kasasi terhadap putusan Pengadilan Pajak dimaksudkan karena pajak memegang peranan penting dan strategis dalam penerimaan negara, oleh karena itu dalam penyelesaian sengketa pajak diperlukan jenjang pemerikasaan ulang vertikal yang lebih ringkas.

Memperbanyak jenjang pemeriksaan ulang vertikal akan mengakibatkan potensi pengulangan pemeriksaan menyeluruh. Satu-satunya upaya hukum yang dapat diajukan terhadap putusan Pengadilan Pajak adalah PK ke Mahkamah Agung, ketentuan mengenai hal ini dapat ditemukan dalamPasal 77 ayat (3) UndangUndang Nomor 14 Tahun 2002 tentang Pengadilan Pajak. PK merupakan upaya hukum luar biasa, disamping akan mengurangi jenjang pemeriksaan ulang vertikal, juga penilaian terhadap kedua aspek pemeriksaan yang meliputi aspek penerapan hukum dan aspek fakta-fakta yang mendasari terjadinya sengketa perpajakan akan

\footnotetext{
${ }^{9}$ Ida Ayu Putu Widiati, Penagihan Pajak Dengan Surat Paksa Sebagai Sarana Intensifikasi Pajak, Eresco, Bandung, hlm.13
} 
dilakukan sekaligus oleh MahkamahAgung. Prosedur seperti ini di satu pihak dapat berdampak positif karena tidak perlu berlarutlarut dalam penyelesaian sengketa, akan tetapi di lain pihak hal yang demikian dapat juga berdampak negatif bagi wajib pajak dan penanggung pajak apabila diperlakukan kurang adil dengan putusan pengadilan pajak, serta dipandang dapat mengurangi hak wajib pajak dalam upaya mencari keadilan.

\section{Faktor-Faktor Yang Menghambat Penyelesaian Sengketa Pajak}

Sengketa pajak muncul sebagai akibat wajib pajak tidak puas dengan besarnya utang pajak yang ditentukan oleh fiscus, serta kemungkinan lain adalah penerapan peraturan perundangan pajak yang tidak tepat, sehingga wajib pajak merasa dirugikan. Mengingat hukum pajak adalah membahas hak dan kewajiban baik bagi wajib pajak maupun fiscus, maka ketika wajib pajak merasa dirugikan oleh keputusan fiscus, maka adalah hak wajib pajak untuk menuntut penyelesaian. Banyak kalangan yang mengkhawatirkan keadaan ini akan mempengaruhi independensi hakim dalam memeriksa dan memutus perkara. ${ }^{10}$

Dalam Hukum Pajak Indonesia penyelesaian sengketa pajak diselesaikan melalui beberapa saluran/lembaga, yaitu keberatan, banding, gugatan, dan peninjauan kembali. Ketentuan tentang lembaga tertentu guna menyelesaikan sengketa pajak tersebut diatur secara tegas dalam Hukum Pajak formal. Penyelesaian sengketa pajak melalui lembaga keberatan, banding, gugatan dan peninjauan kembali dilakukan oleh institusi tertentu yang ditentukan oleh undangundang pajak. Koreksi pemeriksa menyebabkan pajak menjadi kurang bayar dan masih ditambah sanksi sesuai ketentuan peraturan pajak yang berlaku. ${ }^{11}$

Menurut analisa penulis faktor-faktor yang dapat menghambat penyelesaian sengketa pajak di Pengadilan Pajak adalah sebagai berikut:

a) Bidang Administratif

Persyaratan keharusan membayar 50\% (limapuluh persen) dari jumlah pajak terutang dari Wajib Pajak, sebelum mengajukan permohonan banding, telah melanggar asas praduga tak bersalah. Tujuan Wajib Pajak mengajukan permohonan banding ke Pengadilan Pajak pada hakikatnya karena menolak penetapan pajak dari fiskus dan menolak keputusan keberatan yang diajukan DirJend Pajak. Oleh Wajib Pajak, DirJend Pajak dianggap telah bersalah dan melanggar ketentuan hukum yang berlaku dalam mengambil keputusan dan menentukan jumlah pajak terutang, oleh karenanya Wajib Pajak memohon agar pengadilan mengeluarkan putusan agar membatalkan keputusan dari Dirjen Pajak dimaksud.

\footnotetext{
${ }^{10}$ Adrian Sutedi, 2013, Hukum Pajak, Ed: Tarmizi, Cetakan kedua, Sinar Grafika, Jakarta, hlm 251.

${ }^{11}$ Fidel, 2014, Op.cit, hlm 28.
} 
Namun dengan adanya ketentuan keharusan membayar terlebih dahulu setengah dari kewajiban Wajib Pajak, berarti Wajib Pajak dianggap telah bersalah. Secara a contrarium Dirjen Pajak dianggap telah benar dan tidak melanggar ketentuan hukum dalam mengambil keputusan menentukan jumlah pajak terutang. Ketentuan ini pun telah melanggar asas keadilan dan HAM karena hak Wajib Pajak untuk memperoleh keadilan melalui institusi Pengadilan Pajak telah di kebiri dengan adanya kewajiban melaksanakan terlebih dahulu keputusan tersebut, walaupun hanya sebagian. Pada hal keputusan tersebut belum atau akan diuji kebenarannya oleh hakim di pengadilan, artinya ada kemungkinan keputusan tersebut bertentangan dengan peraturan hukum dan harus dibatalkan.

b) Bidang yudisial

Yaitu mengenai kewajiban Hakim untuk menghadirkan pihak terbanding atau tergugat dalam pemeriksaan dipersidangan. Berdasarkan Pasal 46 UndangUndang Pengadilan Pajak disebutkan "bahwa pemohon banding atau penggugat dapat memberitahukan kepada Ketua untuk hadir dalam persiapan untuk memberikan keterangan lisan". Kata-kata "dapat" mengandung arti bahwa tidak ada kewajiban hakim untuk menghadirkannya dipersidangan. Dengan demikian pemohon banding atau penggugat tidak mutlak mempunyai hak untuk hadir dipersidangan, karena dengan kata-kata dapat tersebut keputusan untuk bisa hadir atau tidak pemohon banding atau penggugat dipersidangan ditentukan oleh Hakim, berdasarkan perlu atau tidaknya pemohon banding atau penggugat dimintakan keterangannya dipersidangan.

Hal ini berarti telah melanggar hak Wajib Pajak selaku pemohon banding atau penggugat untuk membela kepentingannya semaksimal mungkin dengan menyampaikan pendapatnya secara lisan dipersidangan. Kendala dibidang yudisial lainnya adalah tidak adanya kesempatan untuk menempuh upaya hukum biasa bagi para pihak yang bersengketa, dan hanya ada upaya hukum luar biasa berupa PK ke Mahkamah Agung. Hal ini dianggap telah melanggar hak untuk memperoleh keadilan dengan cara mengajukan pemeriksaan ulang vertikal kepada institusi pengadilan yang lebih tinggi sesuai dengan sistem yang secara umum berlaku.

Mengenai kewajiban Hakim untuk menghadirkan pihak terbanding atau tergugat dalam pemeriksaan dipersidangan. Berdasarkan Pasal 46 UndangUndang Pengadilan Pajak disebutkan "bahwa pemohon banding atau penggugat dapat memberitahukan kepada Ketua untuk hadir dalam persiapan untuk memberikan keterangan lisan". Kata-kata "dapat" mengandung arti bahwa tidak ada kewajiban hakim untuk menghadirkannya dipersidangan. Dengan demikian pemohon banding atau penggugat tidak mutlak mempunyai hak untuk hadir dipersidangan, karena dengan kata-kata dapat tersebut keputusan untuk bisa 
hadir atau tidak pemohon banding atau penggugat dipersidangan ditentukan oleh Hakim, berdasarkan perlu atau tidaknya pemohon banding atau penggugat dimintakan keterangannya dipersidangan. Hal ini berarti telah melanggar hak Wajib Pajak selaku pemohon banding atau penggugat untuk membela kepentingannya semaksimal mungkin dengan menyampaikan pendapatnya secara lisan dipersidangan. Kendala dibidang yudisial lainnya adalah tidak adanya kesempatan untuk menempuh upaya hukum biasa bagi para pihak yang bersengketa, dan hanya ada upaya hukum luar biasa berupa PK ke Mahkamah Agung. Hal ini dianggap telah melanggar hak untuk memperoleh keadilan dengan cara mengajukan pemeriksaan ulang vertikal kepada institusi pengadilan yang lebih tinggi sesuai dengan sistem yang secara umum berlaku.

\section{Kesimpulan}

Jaminan hukum bagi wajib adalah penerapan hak-hak wajib pajak yang tidak terkait dengan peradilan pajak. Sementara itu jaminan hukum wajib pajak melalui peradilan pajak dilakukan dalam bentuk penggunaan hak-hak wajib pajak yang terkait dengan peradilan pajak, seperti keberatan, banding, gugatan, dan peninjauan kembali sebagai upaya hukum dalam hukum pajak. Faktor-faktor yang menghambat proses penyelesaian sengketa pajak adalah faktor di bidang Administratif yaitu adanya keharusan terlebih dahulu wajib pajak membayar 50\% (limapuluh persen) dari jumlah pajak yang terutang. Kemudian dibidang Yudisial yaitu mengenai kewajiban Hakim untuk menghadirkan pihak terbanding atau tergugat dalam pemeriksaan dipersidangan.

\section{Referensi}

Adrian Sutedi, 2013, Hukum Pajak, Ed: Tarmizi, Cetakan kedua, Sinar Grafika, Jakarta.

Etty Rochaeti, 2012, Perlindungan Hukum Bagi Wajib Pajak Dalam Penyelesaian Sengketa Pajak, Jurnal Wawasan Hukum, Volume 26

Fidel, 2014, Tax Law : Proses Beracara di Pengadilan Pajak d an Peradilan Umum, Tangerang: PT Carofin Media, Jakarta.

Ida Ayu Putu Widiati, Penagihan Pajak Dengan Surat Paksa Sebagai Sarana

Intensifikasi Pajak, Eresco,Bandung

Marihot P. Siahaan, 2005, Pajak Daerah \& Retribusi Daerah, PT RajaGrafindo Persada, Jakarta.

Rochmat Soemitro, 1990, Dasar-dasar Hukum Pajak Dan Pajak Pendapatan, Eresco, Bandung. ,1990, Asas Dan Dasar Perpajakan Jilid 1, Eresco, Bandung

SF.Marbun, 1997. Peradilan Administrasi Negara Dan Upaya Administratif Di 
Jaminan Hukum Terhadap Wajib Pajak Dalam Penyelesaian Sengketa Pajak

Indonesia, Liberty, Yogyakarta.

Sutrisno, 2010, Penyelesaian Sengketa Pajak, Liga Hukum 